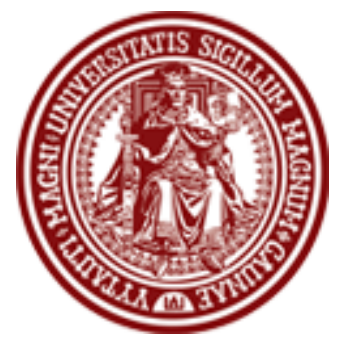

BALTIC JOURNAL OF LAW \& POLITICS

VOLUME 4, NUMBER 1 (2011)

ISSN 2029-0454

http://www.versita.com/bjlp

Cit.: Baltic Journal of Law \& Politics 4:1 (2011): 52-82

DOI: $10.2478 / \mathrm{v} 10076-011-0003-6$

\title{
FAITH, ETHICS AND RELIGIOUS NORMS IN A GLOBALIZED \\ ENVIRONMENT: FREEDOM OF RELIGION AS A CHALLENGE TO \\ THE REGULATION OF ISLAMIC FINANCE IN EUROPE
}

\author{
Stefan Kirchner \\ Researcher \\ Georg August University, Faculty of Law (Germany) \\ Doctoral Student \\ Justus Liebig University, Faculty of Law (Germany) \\ Attorney at Law (Rechtsanwalt, admitted to the bar in Germany) \\ Rechtsanwaltskanzlei Kirchner, Frankfurt am Main (Germany)

\section{Contact information} \\ Address: Rechtsanwaltskanzlei Kirchner, Platz der Einheit 1, 60327 Frankfurt am Main, \\ Germany \\ Phone: +49(176)23890182 \\ E-mail address: mail@humanrightslawyer.eu
}

Received: January 11, 2011; reviews: 2; accepted: May 28, 2011.

\begin{abstract}
It is often feared that globalization is an equalizer in that it dissolves the differences between cultures, including legal cultures. At the same time we can see a counter-movement which places more emphasis on culturally or religiously based rules. A key example of this is the emergence of Islamic Finance. This trend has not only been fueled by the renewed interest in Islam since 9/11, but also due to the shortcomings of traditional financial concepts which have been highlighted dramatically in the global financial crisis. While originating in the Middle East, interest in Islamic finance is now so widespread that seminars on Islamic finance in Western financial centers are fully booked long in advance. International law firms open more and more new offices in the Middle East and, while not necessarily having entered the mainstream, in a sense Islamic finance has gained its place in the world of finance and has therefore become a concern not only for bankers but also for lawyers advising clients on
\end{abstract}


financial services. In this presentation, we will first look at the Quranic sources for the need for Islamic finance before seeing how Islamic finance operates and which financial instruments have been developed under sharia law. We will see how sharia rules impact the financial industry and how they have gained a role among financial products offered around the world before turning our attention to the challenge posed by these financial instruments to regulators unfamiliar with Islamic law. We will look at how religious freedom limits regulatory possibilities. At the center of the investigation, though, will be the question as to whether Islamic finance products live up to the promises associated with them and which consequences this has for regulators, in particular those in Non-Muslim countries.

\section{KEYWORDS}

Human rights, freedom of religion, religion, Islam, sharia, finance, banking

\section{NOTE}

The author thanks E. Azik, LL.M., for information about the banking industry in Turkey, ref. jur., Dipl.-Jur. H. Farouq for information about Islam and Dr. theol. U. Pękala as well as B. Rossmanith for early access to their recent research on theology and tolerance. All opinions expressed and any mistakes contained in this article, though, are solely to be attributed to the author. This text is dedicated to the eternal memory of Fr. Thair Sad-alla Abd-al, Fr. Waseem Sabeeh Al-kas Butros and their companions. 


\section{INTRODUCTION}

Unlike other countries in Northern Europe, Islam has long been part of Lithuania, at least since Grand Duke Vytautas the Great extended the borders of the Grand Duchy of Lithuania to the Northern shores of the Black Sea. This brought Crimean Tartars into the population of the Grand Duchy, a number of whom later migrated towards the Lithuanian heartland. Today several thousand of their descendants live in Lithuania, in particular in the south of the country. Of course the situation in Lithuania differs significantly from the situations in other European countries which, over the last decades, have become home to large numbers of Muslim immigrants. Apart from that, Lithuania has been connected to the Muslim world through the ancient trading routes connecting the Baltic Sea to Miklagard, modern day Istanbul, the Soviet occupation (which brought Lithuania under the same flag as the predominantly Muslim people of Central Asia), and more recently and still modestly through its membership in the European Union and the Schengen Area.

Globalization, though, has changed the ethnic composition of many countries, ${ }^{1}$ in particular in Western Europe. In Germany, among other nationalities, Turkish workers were invited to add to the workforce needed for the reconstruction and improvement of West Germany's industry-based economy. Similarly, there are significant Moroccan and Turkish minorities in the Netherlands and Belgium. The situation is different again in France and Britain, where the Muslim population often comes from former colonies and often has easier access to citizenship. This increased number of members of minority religions in Western countries comes at a time when religion matters again - not only in private but also politically. ${ }^{2}$

Even though there were times when it was considered by some to be unacceptable for a Muslim to live in predominantly Christian lands, ${ }^{3}$ economic considerations have overruled theological constraints in millions of cases and the existence of large Muslim minorities in Europe is a fact that needs to be dealt with. Immigration poses a challenge to the self-definition of Western states and raises a

\footnotetext{
${ }^{1}$ A good overview on migration streams can be found at [No author named], "Migration - viele Gründe, viele Grenzen [Migration - many reasons, many borders]": 17; in: Alain Gresh, Jean Radvanyi, Philippe Rekacewicz, Catherine Samary, and Dominique Vidal, eds., Atlas der Globalisierung [Atlas of Globalisation], $2^{\text {nd }}$ ed. (Paris: Le Monde diplomatique, 2010).

${ }^{2}$ Cf. [No author named], "Fundamentalisten sind überall [Fundamentalists are everywhere]": 24; in: Alain Gresh, Jean Radvanyi, Philippe Rekacewicz, Catherine Samary, and Dominique Vidal, eds., Atlas der Globalisierung [Atlas of Globalisation], $2^{\text {nd }}$ ed. (Paris: Le Monde diplomatique, 2010).

${ }^{3}$ Cf. Amin Maalouf, Der Heilige Krieg der Barbaren - Die Kreuzzüge aus der Sicht der Araber [The Holy War of the Barbarians - The Crusades from the perspective of the Arabs], $5^{\text {th }}$ ed. (Munich: Deutscher Taschenbuch Verlag, 2008), p. 11; Leonard Patrick Harvey, Islamic Spain 1250 to 1500 (Chicago: University of Chicago Press, 1990), p. 56
} 
number of issues which have to be resolved. ${ }^{4}$ At the same time that these minorities grow both in absolute numbers ${ }^{5}$ as well as in relative terms, ${ }^{6}$ many of these immigrants feel alienated. The prohibition of minarets in Switzerland ${ }^{7}$ and the French ban on certain Islamic veils (commonly referred to as the burqa ban but also including niqabs and referred to by French lawmakers as the law prohibiting the covering of faces in public $^{8}$ ) are only two of the many reasons why Muslims often do not feel welcome in Europe. This anti-Islamic attitude has its roots not only in post-9/11 sentiments; rather, although European politicians are loathe to admit so, the long-running conflict with Islam is still very much in the hearts, if not on the minds of the majority of Europe's population.

It should also be noted that there are a number of converts to Islam in Western countries, and a significant number of comparatively well-off Muslims live in Western countries due to the living standard provided there. Being in a predominantly foreign environment leads to concentration on issues such as a shared faith, language or cultural background. Often emigration leads to an increasing interest in religion and culture since these are often perceived as connections to the homeland - even if the emigration in question occurred several generations earlier. This has led to an increased interest in financial service products which are compatible with the teachings of Islam. In addition, the financial services industry is global in nature, growing faster than both global trade and global production ${ }^{9}$ and requiring banks which act globally to offer novel as well as reliable and trustworthy services. The latter becomes particularly important when one remembers that the Islamic world, spanning from the Atlantic coast of Morocco all the way to Indonesia not only is Europe's geographic neighbor but also its largest export market. ${ }^{10}$ Often banks based in Western European countries - with the notable exception of the United Kingdom, where Islamic finance is already part

\footnotetext{
${ }^{4}$ On the current discussion in Germany cf. Jürgen Habermas, "Leadership and Leitkultur," The New York Times (October 28, 2010) //

http://www.nytimes.com/2010/10/29/opinion/29Habermas.html?pagewanted=1\&_r=1\&ref=globalhome.

${ }^{5}$ Cf. Richard Allen Greene, "Mohammed tops list of English baby names," (October 29, 2010) // http://edition.cnn.com/2010/WORLD/europe/10/28/uk.mohammed/index.html?hpt=T2.

${ }^{6}$ Cf. [No author named], "An Uncertain Road: Muslims and the Future of Europe - Muslims and the Future of Europe," The Pew Forum on Religion and Public Life (October 19, 2005) // http://pewforum.org/Muslim/An-Uncertain-Road-Muslims-and-the-Future-of-Europe.aspx.

7 Cf. Marcel Stüssi, "Banning of Minarets: Addressing the Validity of a Controversial Swiss Popular Initiative," Religion and Human Rights 3 (2008).

8 For the text of the law cf. French Law No. 524 of July 13, 2010 // http://www.assembleenationale.fr/13/ta/ta0524.asp.

${ }^{9}$ [No author named], "Mehr Geld als Waren in der Welt [More money than goods in the world]": 66; in: Alain Gresh, Jean Radvanyi, Philippe Rekacewicz, Catherine Samary, and Dominique Vidal, eds., Atlas der Globalisierung [Atlas of Globalisation], $2^{\text {nd }}$ ed. (Paris: Le Monde diplomatique, 2010).

${ }^{10}$ Cheikh A. Soumare, The Principles of Islamic Banking [Thesis submitted to the International Institute of Islamic Banking and Economics, Girne, Turkey], $1^{\text {st }}$ ed. ([No location given]: Xlibris, 2008), p. 2.
} 
of the financial services infrastructure ${ }^{11}$ - aim their offers of Islamic financial services more at predominantly Muslim countries, and only to a lesser extent at Muslims living in the West. ${ }^{12}$ While Deutsche Bank has been offering Shariacompliant products abroad for some time, ${ }^{13}$ Kuveyt Türk Deutschland, ${ }^{14}$ the German branch of Kuvyet Türk Bank, which offers Islamic financial services, opened its first office in Germany in March 2010. ${ }^{15}$ Technically speaking, Kuveyt Türk Deutschland does not offer Islamic financial services, but works via its Turkish offices because Kuveyt Türk Deutschland still lacks the necessary permit. ${ }^{16}$ Kuveyt Türk Deutschland reports positive signals from BaFin, the responsible German regulatory agency. ${ }^{17}$ Although some four million Muslims are said to live in Germany, ${ }^{18}$ Islamic finance is still not very well known there. ${ }^{19}$ This might have to do with the fact that it is not particularly popular in general among Muslims (even in Saudi Arabia only 10 to $12 \%$ of all financial transactions are sharia compliant ${ }^{20}$ ). At the same time, the need for effective and trustworthy regulation is relatively high in Germany because in the 1990s fraudulent offers of sharia compliant investments targeting Turkish immigrants to Germany led to losses of millions of Euros among some 300,000 savers. $^{21}$ Against this background the need for regulation which can rebuild the trust of consumer-investors becomes evident.

This article aims at raising awareness of the issues covered here among nonMuslims in order to improve regulatory work in non-Muslim states with a view to the legitimate interests of investors of Muslim faith. Even if one reject the teachings of Islam, one still needs to respect the freedom of religion of the Muslim faithful. It is their own decision to follow their faith and when we disagree with them but respect this decision, we also have to allow the necessary consequences, as far as they do not fundamentally conflict with the ordre public of the society as such in an unacceptable manner. This high status of the freedom of religion is emphasized for

${ }^{11}$ Cf. Michael Ainley, Ali Mashayeki, Robert Hicks, Arshadur Rahman, and Ali Ravalia, Islamic Finance in the UK: Regulation and Challenges, $1^{\text {st }}$ ed. (London: Financial Services Authority, 2007).

12 Mahmoud Amin El-Gamal, "Overview of Islamic Finance, [United States] Department of the Treasury," Occasional Paper No. 4 (August 2006) ([United States] Department of Treasury, Office of International Affairs): 2 //

http://www.ustreas.gov/offices/international-affairs/occasional-paper-

series/08042006_OccasionalPaper4.pdf.

13 [No author named], "Deutsche Bank launches Shari`a mutual fund capability - Initial five funds unveiled in Dubai and Bahrain today," Press Release (December 6, 2006) // http://www.deutschebank.de/medien/en/content/press_releases_2006_3265.htm?dbiquery=null:islamic\%20finance.

${ }^{14}$ It had been hoped to give the readers an inside view of Islamic finance in Germany but a request for an interview with Kuyet Türk Deutschland's CEO Ugurlu Soylu or other Kuyet Türk staff involved in Islamic financial services in Germany was not yet answered at the time this article was submitted.

${ }^{15}$ Benno Stieber, "Allahs Banker [Allah's Banker]," enorm No. 4 (November 2010 - February 2011): 113.

${ }_{16}^{16}$ Ibid.: 114

17 Ibid.

${ }^{18}$ Ibid.: 113.

${ }^{19}$ Ibid.

${ }^{20}$ Ibid.: 114.

${ }^{21}$ Ibid.: 115. 
example in Art. 4 of the German constitution, the Grundgesetz, which does not allow for any restrictions of the freedom of religion, with the exception of the constitutionally protected rights of others, of course. But also other Western countries which limit the freedom of religion usually do so only sparingly. As a rule of thumb, limits to the freedom of religion must be based on the need to protect values of a similar magnitude. The freedom of religion does not justify murder or terrorism, nor female genital mutilation or similar crimes. But the role played by religion in the everyday life of large parts of the population is currently underestimated by both law-makers and legal scientists. While an emphasis on religion is, to say the very least, not popular in mainstream academia, it should be kept in mind that law is largely reactive. Law reflects the society which creates it and it usually reacts to the factual situation. Even when law is used as a tool to shape facts and to alter a society, it is used so in a way so as to react to a perceived need for such a change. Thus, this text is not only about law and finance; at the same time it is also about politics, faith and the cultural identity of Europe. In the current discussions on how to draw the lines between state and religion and how to deal with the large Muslim minorities in many European countries, lawyers cannot afford to see only one dimension of the problem before us.

That such a text is being written about Islamic Finance is necessary due to the importance of religion in the lives of people as well as to the fact that Islamic Finance is becoming more and more important in countries which are not predominantly Muslim but which are home to a notable Muslim minority.

It is not my aim to speak authoritatively about the teachings of the Quran, since I am not an Islamic scholar. It is also not the purpose of this text to evaluate whether the instruments offered in the context of Islamic Finance are meaningful from a financial perspective, since the author is not an expert in Finance. The goal is different: we will investigate, whether Islamic Finance lives up to the promise of being compatible with the teachings of the Quran. In this sense, this text is legal in nature, since it tests the facts of Islamic Finance against the standards set by the Quran.

It is my thesis that, from a legal perspective, Islamic finance can be allowed even in the predominantly Christian or secular states of Western Europe. Whether it should be allowed is a political decision which rests with the democratically elected legislators. ${ }^{22}$ It is they, on behalf of their people(s), who must make this choice. But

\footnotetext{
22 The debate is by no means restricted to Islamic finance. It also plays a key role in family and inheritance law, although this debate seems to be more relevant in Common law countries due to the implied limit set by the ordre public in many legal systems of Continental Europe. A first insight into the debate in the United States and Britain for example is provided by Stanley Fish (see Stanley Fish, "Serving Two Masters: Sharia Law and the Secular State," New York Times (October 25, 2010) //
} 
if it is allowed, it also needs to be regulated for the benefit of the investors in order to prevent fraud to the detriment of the financial interests of the investors.

We will begin our investigation by looking at what the Quran actually teaches in terms of finance (1.), how Islamic Finance responds to the demands of the Quran and the sharia through the many different financial instruments which have been developed under this label, although we will only be able to look at a few of them as exemplary case studies (2.). We then will evaluate these instruments by comparing their compliance with the letter of the law to the spirit of the law (3.) before looking briefly at human rights aspects (4.) and, maybe most interestingly from a non-Muslim perspective, at challenges Islamic finance poses for regulators in Western non-Muslim countries (5.). In the final part we will try to put the picture together and draw our conclusions.

\section{THE TEACHINGS OF THE QURAN AND THE SHARIA}

\subsection{INTRODUCTION}

The Quran prohibits riba as one of the al-Saba al-Mubiqat, the seven serious sins in Islam. ${ }^{23}$ Riba is often translated as usury or interest, ${ }^{24}$ making it necessary for faithful Muslims, who are as in need of modern financial instruments as any other investor, to have at their disposal means to comply with the demands of modern finance as well as the demands of their faith.

One aim of the law should be to aid in the creation of a fair and just society in which work and wealth are directly connected. Many rules of Islamic finance serve this purpose, at least initially. In fact, both intentions can also be found in Christian thought ${ }^{25}$ : namely, the rule that who does not work shall not eat, ${ }^{26}$ and the consequential prohibition of interest. ${ }^{27}$ But this is all based on the notion that God's

http://opinionator.blogs.nytimes.com/2010/10/25/serving-two-masters-shariah-law-and-the-secularstate/).

${ }^{23}$ [No author named], "Riba" // http://en.wikipedia.org/wiki/Riba.

${ }^{24}$ We will look at the concept of Riba more closely below at 1.4.

25 It is noteworthy that the parable in Matthew 25 (in particular Matthew 25:27, see also the similar parable in Luke 19, there especially Luke 19:23) does not necessarily constitute an endorsement of interest by Jesus. To the contrary, it has to be noted that Jesus used situations his listeners were familiar with to transport His teachings. It is actually possible to see a certain aversion of Christ against money, most evidently in Luke 16:13 and Matthew 6:24. Other examples include the fact that it is Judas Iscariot who is tasked with managing the group's finances, rather than Jesus himself (John 12:6, John 13:29) but also in His treatment of the money-exchangers in the temple (John 2:15). Money is clearly a thing of this world and which Jesus refers to as such when he refers to the picture of the emperor on the coin (Matthew 22:21). Jesus recognized the role money plays in society and used this reality in His teachings, e.g. in the parable of the woman and the lost coin (Luke 15:8-10) or the gift of the poor widow (Luke 20:45-21:4).

${ }^{26} 2$ Thessalonians 3:10.

${ }^{27}$ An interesting overview is provided by Clyde G. Reed and Cliff T. Bekar (see Clyde G. Reed and Cliff T. Bekar, "Religious Prohibitions against Usury" (January 21, 1999) // http://www.appropriateeconomics.org/materials/Why\%20do\%20religions\%20prohibit\%20usury.htm. 
plans for humans are good in general, ${ }^{28}$ either directly or by providing for a more just society from which individual benefits. Consequently the Christian reader will find a lot of familiar thoughts in texts on Islamic finance, such as the idea that when you let your money "work" for you, it is not really money which works but other people who are creating profits. ${ }^{29}$ It is no coincidence that it was long considered wrong for Christians to lend money and charge interest for it. While Islamic finance follows a more literal approach, the Christian approach (which, more correctly, should be referred to as the Catholic approach, since protestant churches have virtually abandoned original Christian social teachings in favor of, for example, Calvinist-style capitalism) has led inter alia to the Friars Minor, better known as the Franciscans, who have played a notable role in establishing community banks with the aim of limiting the negative effects modern finance can have on individuals. ${ }^{30}$ The key difference between Catholic and Islamic business ethics is that one focuses on the form (Islam) and the other on substance (Catholicism). Effective regulation can actually help Islamic financial service providers provide a better service to their customers, who usually are interested in the substance of ethical investment more than in its mere form. ${ }^{31}$

\subsection{THE QURAN}

When talking about the Quran, it has to be kept in mind that this book has a special role in the life of Muslims. Often even secular Muslims will treat an old copy of the book with more respect than most people afford to books, be it that it will always be on top of a pile of books, not in the middle, or that they will not even leave it open when they stop reading. For Muslims the Quran is written by God himself, which explains the unique respect it commands. In a sense the Quran for Muslims is more than a holy book; it is the closest thing to the real presence of God on Earth in Islam, which makes its relative position in Islam somewhat comparable to the importance the Eucharist holds for Catholics. While secular "Christians" might not even own a bible, even many secular Muslims will give reference to the Quran by virtue of its being more than just a book.

At the same time the Quran is the source of the Islamic law, the sharia. In this investigation, it is exclusively this aspect which we will deal with. In this sense, our investigation is strictly legal in nature without claiming to be able to make any assumptions or conclusions about the theological aspects of Islamic finance.

\footnotetext{
28 Jeremiah 29:11.

29 Paulus Terwitte, Das Leben findet heute statt! Ein Anschlag auf die Vertröstungsgesellschaft [Life happens today - An attack against the society of promises for the future], $1^{\text {st }}$ ed. (Reinbek bei Hamburg: Rowohlt, 2009), p. 217.

${ }^{30}$ Ibid.

${ }^{31}$ Benno Stieber, supra note 15: 115.
} 
In this context it is important to remember the meaning of the word Islam submission. ${ }^{32}$ The root word for Islam is istaslama, meaning "to submit" or "to surrender". Not Islam ${ }^{33}$ but the related word salam means peace. ${ }^{34}$ While the Christian faith teaches how to live, Islam often provides answers as to what to do. ${ }^{35}$ The Quran is usually understood much more literally than the Bible, which, in particular in the gospels, contains for example a number of parables. A textual critique of Biblical texts which are the word of God is possible in so far as the human authors have been inspired by God when they wrote the text. Christian theologians might argue how to understand a certain passage of the Bible, but from a Muslim perspective the Quran is not open to such a degree of critical interpretation, nor, actually, to translation, since it is considered to be the word of God which is believed not to have been phrased by humans but is said to have been dictated verbatim to the Prophet Muhammad by the Angel Jibril. With this perceived authority the Quran "provides a detailed code of conduct for the individual believer - an outline, indeed, of a code of law. [...] In short, it is concerned with just about every facet of everyday life." ${ }^{36}$ Certainly, this is part of the appeal of Islam to many converts who seek some kind of spiritual guidance, just like Westernized versions of Buddhism are appealing for providing a kind of spirituality which gives the illusion of freedom. We will see in a moment how this literal approach to understanding the Quran, as opposed to the approaches of Christian theologians to the Bible, raises problems with sharia law from a Western perspective.

Because in most predominantly Muslim states religious laws, the sharia, and secular laws coexist ${ }^{37}$ (although latter might be based on the sharia or inferior to it), the creation of new instruments of Islamic finance requires the cooperation of financial experts, secular lawyers and sharia jurists. ${ }^{38}$ Not unlike lawyers in common law systems, sharia jurists place great emphasis on precedents, which are not overruled easily. ${ }^{39}$ This reliance on precedents has caused sharia law to suffer from the same problem many common law systems are afflicted with - the relative inaccessibility of the law to non-jurists, which in turn perpetuates the position of

\footnotetext{
32 [No author named], "The Meaning of Islam" //

http://www.wikiislam.net/wiki/The_Meaning_of_Islam.

${ }^{33}$ Ibid.

${ }^{34}$ Ibid.

${ }^{35}$ Cf. Cheikh A. Soumare, supra note 10, p. 17.

${ }^{36}$ Ibid.

${ }^{37}$ Ibid., p. 21.

${ }^{38}$ Cf. ibid.; [no author named], "Sharia Board" //

http://wiki.islamicfinance.de/index.php/Shariah_Board\#Certification_Process. On the role of Sharia jurists cf. Michael Gassner, "How to balance form and substance - the role of Sharia Scholars," (August 11,2008 ) // http://www.islamicfinance.de/?q=node/1461.

${ }^{39}$ Cheikh A. Soumare, supra note 10, p. 21.
} 
power of the muftis over the other groups of experts involved in the process of creating new financial instruments.

\subsection{FATWA}

The key method of creating instruments of Islamic finance is the fatwa. ${ }^{40} \mathrm{~A}$ fatwa is a legal ruling, an advisory opinion rather than a judgment. Every Muslim may ask a mufti, a scholar of Islam, ${ }^{41}$ for clarification in issues in which it is unclear, which behavior is required by the Muslim faith. ${ }^{42}$ The fatwa is a recommendation, not a binding legal decision ${ }^{43}$ by an officially appointed authority. But it can serve as evidence that a specific financial product complies with the sharia. In that sense, muftis certify the financial products and allow banks to label the product in question as "Islamic". As an instrument of what international lawyers would most likely consider to be merely soft law, fatwas gain their relevance from the professional authority of the person who issues it as well as the pervasiveness of the reasons given for the fatwa. Since fatwas can differ significantly in length from a few lines to hundreds of pages, ${ }^{44}$ short fatwas are often seen as sufficient since they can be used to answer the question whether a certain conduct is permitted.

Due to the importance of precedent in sharia law, ${ }^{45}$ access to earlier decisions is important, yet it is here where the Islamic legal system contains a major technical flaw: the lack of an organized court structure and a clear hierarchy in Islam and the resulting relative independence of muftis make it difficult to ensure knowledge of all relevant precedents. In recent years the creation of online databases on existing fatwas has aided those seeking access to sharia law at least a little bit, ${ }^{46}$ but the sheer number of fatwas and the lack of a true hierarchical structure in Islam puts these databases at risk of being incomplete and makes the

\footnotetext{
40 For a general overview cf. Mughees Shaukat, General Perception of Fatwa and its Role in Islamic Finance, $1^{\text {st }}$ ed. (Kuala Lumpur: INCEIF, 2009), pp. 7 et seq., and Saiful Azhar Rosly, "The role of the fatwa in Islamic finance," Investor Digest (January 16, 2003): 28.

${ }^{41}$ Cf. Anne-Sophie Fröhlich and Claudia Stodte,"Islam von A bis Z," Der Spiegel Geschichte No. 5: Der Islam: 1400 Jahre Glaube, Krieg und Kultur (2010): 57.

42 Ibid.: 52.

${ }^{43}$ Ibid.

${ }^{44}$ Ibid.

${ }^{45}$ Cheikh A. Soumare, supra note 10 , pp. 20 et seq.

46 A database of fatwas can be found e.g. at http://www.e-fatwa.gov.my. Other websites provide information on Islamic finance in the form of articles or databases which contain contact information for researchers, e.g. http://www.islamic-finance.com; http://islamonline.com/islamic-finance/islamicfinance-library.html; http://www.islamicfinance.de. Also, fatwa collections are being circulated in Islamic circles (cf. http://www.mail-archive.com/muslim@yahoogroups.com/msg02330.html). None of these services seems to be able to provide a complete and authoritative description of the situation under Sharia law. On a national level, Saudia Arabia has established a permanent committee dealing with fatwas and research in 1971:

http://www.fatwa-online.com/scholarsbiographies/15thcentury/permanentcommittee.htm.
} 
required information difficult to access. ${ }^{47}$ At the end of the day banks will always depend on the ruling of a mufti in order to be able to call their product "Islamic". This and the fact that the position of mufti is not necessarily related to paid employment of course includes the risk of abuse. It is the mere possibility that a favorable fatwa might be "bought" by a financial service provider rather than issued based on the factual nature of a financial product which can bring disrepute to the entire business model.

\subsection{RIBA $^{48}$}

The best known concept in Islamic finance certainly is that of riba, ${ }^{49}$ which is expressly forbidden in the Quran: "O you who have believed, do not consume usury, doubled and multiplied, but fear Allah that you may be successful." 50 The term "riba" is often translated as interest but it is unclear whether all interest is prohibited or only excessive interest, that is, usury. Usury is always riba and hence forbidden. ${ }^{51}$ But the question becomes already less clear when interest rates charged by commercial banks are under investigation. ${ }^{52}$ It appears insufficient to dismiss the problem by claiming that those who borrow from commercial banks (as opposed to traditional moneylenders) are usually either businesses or not "from the poorer sections of ${ }^{\prime 53}$ society. While this consideration might be valid in rural areas of less developed Muslim countries (and it already seems doubtful there), it can hardly be applied to Muslims living in modern societies, be it in the Gulf States, Turkey or Europe. Just like state regulators will not be able to decide on such questions of religion, we will have to leave this question open, also due to the constraints of time and space imposed on this research. A few words, though, are necessary to illuminate the idea behind the prohibition of riba: the basic premise on which the prohibition of riba is based is the idea that in order to make an ethically acceptable profit, the investor has to share in the risk inherent in the enterprise

47 Cf. also Mohd Nor Mamat, Siti Fatahiyah Mahamood, Mohd Nazir Ahmad, Aliza Ismail, and Zam Hariro Jamaluddin, "E-Fatwa Information Management: Sustainance and Enhancement towards friendly and efficient online database," World Congress of Muslim Librarians and Information Scientists (November 25 - 27, 2008): $11 / /$

http://ddms.usim.edu.my/bitstream/handle/123456789/1906/E-

Fatwa\%20Information\%20Management.pdf?sequence $=1$.

48 Here only a few concepts of Islamic finance can be elaborated on briefly, for a concise overview see Mahmoud Amin El-Gamal, "A Basic Guide to Contemporary Islamic Banking and Finance," (2000) // http://www.ruf.rice.edu/ elgamal/files.primer.pdf, and Mahmoud Amin El-Gamal, Islamic Finance Law, Economics and Practice, $1^{\text {st }}$ paperback edition, reprint (Cambridge, New York, Melbourne, Madrid, Cape Town, Singapore, Sâo Paulo, Delhi: Cambridge University Press, 2009), pp. 46 et seq.

${ }^{49}$ An overview over the concept of riba from a Western perspective which also deals with other relevant categories of Islamic finance which cannot be dealt with here in detail, such as fiqh and gharar, is provided by Miriam Sophia Netzer (Miriam Sophia Netzer, Riba in Islamic Jurisprudence - The Role of 'Interest', in Discourse on Law and State, $1^{\text {st }}$ ed. (Medford: The Fletcher School, 2004)).

${ }^{50}$ Quran, Sura 3, Verse 310, texts from: [No author named], "Riba", supra note 23.

${ }^{51}$ Cf. Cheikh A. Soumare, supra note 10, p. 32.

52 Ibid., p. 33.

${ }^{53}$ Ibid. 
which eventually leads to the profit in question: "The essential principle of Islamic finance is profit sharing, as the Koran permits profit, but prohibits interest. By this means both the supplier of the capital and the borrower share in the risks, and both prosper when returns are favorable, and suffer together when returns are poor. ${ }^{154}$ Or as the Quran puts it: "Allah has permitted trade and has forbidden interest[.]"55

\section{INSTRUMENTS OF ISLAMIC FINANCE - AN INTRODUCTION}

\subsection{CREDIT}

\subsubsection{LONG-TERM CREDIT: MUDARABAH AND MUSHARAKA}

Contracts, which are characterized by the solidarity between creditor and debtor, and which the prohibition of riba requires, are referred to as mudarabah. ${ }^{56}$ This risk sharing ${ }^{57}$ can be achieved for example if the bank becomes a stakeholder in the company or enters into a silent partnership agreement with it. ${ }^{58}$ The latter construction is referred to a musharaka. ${ }^{59}$ In a musharaka, the bank and the client company create a partnership agreement with the aim of supporting a third, new, limited liability company. ${ }^{60}$

In a mudarabah, the bank shares directly in the profits of the client company while in a musharaka it shares in the profit of the newly created enterprise only. ${ }^{61}$

In either case, the result for the company is the same as if it had lent money from a Western bank, in that the enterprise receives the funds it needs. The bank, though, depends on the economic success of the company. In essence, the bank provides not credit but a form of venture capital, ${ }^{62}$ although it has to be noted that under both models the bank's commitment usually is with a long term perspective. ${ }^{63}$

\footnotetext{
${ }^{54}$ Ibid., p. 39.

55 Quran, Sura 2, Verse 275, texts from: [No author named], "Riba", supra note 23.

${ }^{56}$ Cheikh A. Soumare, supra note 10, p. 39. Arabic spelling taken from: [No author named], "Mudarabah [Mudarabah]" // http://de.wikipedia.org/wiki/Mudarabah.

57 On risk management in Islamic finance cf. V. Sundararajan and Lucca Errico, "Islamic Financial Institutions and Products in the Global Financial System: Key Issues in Risk Management and Challenges Ahead," International Monetary Fund Working Paper WP/02/192 (2002): 7 et seq. // http://papers.ssrn.com/sol3/papers.cfm?abstract_id=880303, and Andreas A. Jobst, "Risk Management of Islamic Finance Instruments," QFINANCE //

http://www.qfinance.com/contentFiles/QF01/94fqn4jz/10/0/risk-management-of-islamic-financeinstruments.pdf.

${ }^{58}$ Cheikh A. Soumare, supra note 10, p. 40.

${ }^{59}$ Ibid. Arabic spelling taken from: [No author named], "Al-Musharaka" //

http://en.wikipedia.org/wiki/Al-Musharaka.

${ }^{60}$ Cheikh A. Soumare, supra note 10, p. 40.

${ }^{61}$ Ibid.

62 Cf. also Tariq Al-Rifal and Aamir Khan, "The Role of Venture Capital in Contemporary Islamic Finance," (2000): 8 et seq. // http://www.kantakji.com/fiqh/Files/Finance/44437.pdf.

63 Ibid. 42.
} 
When it comes to Public Private Partnerships, ${ }^{64}$ the concession model ${ }^{65}$ seems to be compatible with the prohibition of riba because of its similarities to rent or usufruct. As of now, only Turkey, which for all economic purposes has long been the leading nation of the Islamic world, might be in the best position to gain practical experience in this field, since it does not suffer from the autocratic forms of government which exist elsewhere in the Muslim world. The secular nature of the Turkish state, though, will make it unlikely that PPP agreements there will be explicitly Islamic.

\subsubsection{SHORT TERM CREDIT: MURĀBAHAH AND IJARA}

For short term credit, the murābahah ${ }^{66}$ model is better suited. ${ }^{67}$ Murābahah is essentially a form of resale contract: ${ }^{68}$

Under murabahah schemes, a bank will purchase a commodity on behalf of its client and then sell it to the client at a later date for a premium. The bank makes its profit on the resale premium and as the bank itself is buying and selling [the goods, the bank] is engaged in [a] trading activity rather than usury. Its premium is a reward for its trading role, and this is regarded as legitimate under Islamic law. ${ }^{69}$

For obvious logistical purposes the bank will only take legal rather than factual possession of the goods in question since the goods will be needed by the client for its business and the banks would otherwise incur additional storage and transport costs. ${ }^{70}$ The client of course is expected to pay only at a later time, usually after a previously fixed time not exceeding 180 days. $^{71}$

An alternative method to achieve the results of what in Western finance would be referred to as short-term credit is through ijara, which is similar to tomurābahah with the exception that the item in question is not sold to the client but leased by the client. ${ }^{72}$ Accordingly, the client might pay regular installments rather than one fixed sum. ${ }^{73}$ For taxation reasons, ijara has become popular as the client can use

\footnotetext{
64 Hereinafter: PPP.

65 On the concession model in Public Private Partnerships see Stefan Kirchner, "Public Private Partnerships: Das Konzessionsmodell beim Bau von Straßentunneln," $1^{\text {st }}$ ed. (Munich:Grin Verlag für akademsiche Texte, 2007). On the aspect of risk allocation in this context, which is particularly important for the determination whether the model amounts to riba, cf. Stefan Kirchner, "Private Public Partnerships in Germany: Risk Allocation under the Concession Model," Legal Latitudes 1 (2007).

66 Arabic spelling and transliteration from: [No author named], "Murabaha" //

http://en.wikipedia.org/wiki/Murabaha.

67 Cheikh A. Soumare, supra note 10 , p. 42.

68 Ibid.

69 Ibid., pp. 42 et seq.

70 Ibid., p. 43.

71 Ibid.

72 Cheikh A. Soumare, supra note 10, pp. 43 et seq.

${ }^{73}$ Ibid., p. 44.
} 
the item in question without being its owner, hence, without being taxed for it. ${ }^{74}$ In addition, the running costs of the lease might be offset against the corporate tax owed by the client. ${ }^{75}$

\subsection{INSURANCE}

While the prohibition of riba has already received some attention in nonMuslim literature, the same attention is not yet being given to a number of other aspects of Islamic finance, including the question whether insurance is permissible under the Quran. ${ }^{76}$ The principle of risk sharing already might give non-Western readers an idea of the general adversity to risk which pervades Islamic finance. In the words of a teacher and economist:

In the West, [...] many entrepreneurs deliberately seek out risky projects and ventures. But in the Islamic world there are fewer deliberate risk-takers. [...] Those who take risks are not admired for their daring, nor is it thought particularly desirable that there should be high rewards for risk taking. Indeed[,] risk taking is not viewed as [...] virtuous [at all], but instead as reckless and almost irresponsible. There is great sympathy in Islamic societies for those who fall on hard times through no fault of their own. Less social concern is shown for those who lose as a result of their own risk-taking; in fact some fundamentalists see loss as a just punishment for being reckless. Risk taking is often equated with gambling, ${ }^{77}$

which is forbidden. ${ }^{78}$ The sharing of risk on the other hand is welcomed ${ }^{79}$ and it is the purpose of mudarabah to reward those who share risks. ${ }^{80}$

Insurance is considered similar to gambling, ${ }^{81}$ since the policy holder pays a premium without knowing whether he will ever benefit from the insurance. ${ }^{82}$ In addition, insurance is not seen as a form of risk sharing but rather seen as an encouragement to take future risks, ${ }^{83}$ and at times as "unnecessary, and even selfish" 84 since man is to rely on God: "The Islamic concept that "Allah will provide" means that if the individual seeks to provide for himself he cannot have a strong faith in Allah. ${ }^{\prime 15}$ At first glance here a certain fatalistic streak might be identified in Islamic thought, but what to Westerners might seem fatalistic is for faithful Muslims

\footnotetext{
74 Ibid.

75 Ibid.

${ }^{76}$ Cf. ibid., p. 1.

77 Ibid., pp. 70 et seq.

78 Ibid., p. 71.

79 Ibid.

80 Ibid.

81 Ibid., p. 73.

82 Ibid.

83 Ibid., p. 72.

84 Ibid.

85 Ibid.
} 
simply the awareness that all humans are always in the hand of God. ${ }^{86}$ The Western emphasis on the individual rather than divine providence makes insurance a necessity in the West, since non-religious policy holders in the West will be focused in material goods without keeping in mind humanity's limited nature in the eyes of God. While Christianity does not prohibit insurance per se and places greater importance on human work, it manages to strike a better balance by requiring everybody to work ("If a man will not work, he shall not eat." ${ }^{87}$ ) while reminding people of the need to focus on the supernatural rather than the worldly. ${ }^{88}$ Similarly, both the Quran ${ }^{89}$ and the Bible ${ }^{90}$ speak out against the hoarding of treasures on earth, which could be seen as a form of self-insurance. Forms of mutual insurance on the other hand could be brought in compliance with the sharia much more easily and could be seen in a positive light, ${ }^{91}$ yet for the time being experiences with mutual insurance in the Muslim world are still relatively limited. ${ }^{92}$

\section{IS ISLAMIC FINANCE - FRAUD AGAINST THE FAITHFUL? ${ }^{93}$}

It might be argued that this limited interaction between different approaches to finance, which might be considered a disadvantage from the point of view of those who intend to offer Islamic banking services as the price which needs to be paid in order to have truly Sharia-compliant financial services. But do these instruments really prevent riba? Or do they follow the letter of the law more than its spirit? How far Islamic finance has strayed from the precepts of the Quran can be seen in the current discussion as to whether derivatives are permissible under sharia law. ${ }^{94}$ Derivatives are contracts between seller and buyer concerning a

\footnotetext{
${ }^{86} \mathrm{Cf}$. the remarks by Cheikh A. Soumare, supra note 10, p. 72 , who defends Islam against the charge of fatalism.

872 Thess. 3:10. Interestingly enough, the principle entered Art. 12 of the 1936 Constitution of the USSR, although in particular this constitution was often violated during the Stalin era.

88 Matthew 6:25-34.

89 Sura 9, Verse 35.

${ }^{90}$ Matthew 6:19-21.

91 Cheikh A. Soumare, supra note 10, pp. 79 et seq.

92 Ibid., p. 80.

93 Cf. also Muhammed Saleem, Islamic Banking - A $\$ 300$ Billion Deception - Observations and Arguments on Riba (interest or usury), Islamic Banking Practices, Venture Capital and Enlightenment, $1^{\text {st }}$ ed. ([No location given]: Xlibris, 2005).

${ }_{94}$ Cf. Andreas A. Jobst, "Derivatives in Islamic Finance," (2007) //

http://papers.ssrn.com/sol3/papers.cfm?abstract_id=1015615.pdf; [No author named], "Derivatives dispute divides Islamic finance market," Business Times (February 11, 2009) //

http://www.btimes.com.my/Current_News/BTIMES/articles/devisf/Article/print_html; Dariusz Piotrowski, "Instrumenty pochodne na islamskim rynku finansowym - Derivate Instruments on the Islamic Financial Market [Derivate Instruments on the Islamic Finance Market]," Bank i Kredyt (March, 2007) //

http://ssrn.com/abstract=1007434; see also Bushan K. Jomadar, "Islamic Finance and Securitization: Man-made Tale or Reality," Islamic Law and the Muslim World Paper No. 8-18 (2008) //

http://ssrn.com/abstract=1093064; Andreas A. Jobst, "The Economics of Islamic Finance and Securitization," International Monetary Fund Working Paper WP/01/117 (2007) // http://www.imf.org/external/pubs/ft/wp/2007/wp07117.pdf.
} 
transaction in the future. ${ }^{95}$ The parameters of the deal, that is, the factors which essentially determine the value of a derivative, though, are already agreed on today. ${ }^{96}$ Sometimes derivatives a likened to bets, since the development of their worth depends on external factors, such as the price of a certain stock. However, derivatives can be based on virtually any type of data, such as in the case of weather derivatives which are used as a way to hedge against weather induced risks in certain industries and in the agricultural sector. Derivatives are both investment and insurance tools ${ }^{97}$ and allow future risks to be traded in the first place $^{98}$ by allowing them to hedge risks. Enterprises and financial institutions use derivatives to secure themselves against the risk of unwanted price changes, ${ }^{99}$ and in fact in principle every measurable value (the price of a stock or a commodity, the temperature or amount of rainfall over a given time in a specific location etc.) can serve as underlying support for a derivative. ${ }^{100}$ The idea is that investors who use derivatives become less dependent on the volatility of the cash flow, ${ }^{101}$ thereby reducing the risk for the investor. ${ }^{102}$ In short, derivatives can serve not only as investments but also as insurance. This short description already illustrates that derivatives are hardly compatible with the principles of Islamic finance. That this discussion exists in the first place, despite the nature of derivatives which are much closer in nature to what is referred to in sharia law as "gambling" than insurances are, shows that the substance of the fatwas seems to matter less and less.

While modern financial instruments which are labeled "Islamic" may adhere to the letter of the Islamic law, it is often questionable whether they also adhere to the spirit of the sharia. The rules on which Islamic finance is based are certainly well intended, but this intent is put at risk by the current exclusive focus on forms. If the current practice is not changed, investors will often be led to spend money on financial products which are sharia-compliant only in name. While not called to interpret sharia law, regulators have to ensure that there are no discrepancies

\footnotetext{
95 Stefan Kirchner, "Energiederivatehandel in Skandinavien - Voraussetzungen, Zugangsbedingungen und Entwicklungspotential [Energy Derivative Trading in Scandinavia - Requirements, Access Conditions and potential for Development]": 120; in: Nadine Ruppel, ed., Europäisches und Internationales Energiewirtschaftsrecht, Tagungsband des 9. Graduiertentreffens im Internationalen Wirtschaftsrecht in Gießen 2008 [European and international law of the energy business, Proceedings of the $9^{\text {th }}$ Postgraduate Meeting on International Economic Law in Gießen 2008], $1^{\text {st }}$ ed. (Stuttgart, München, Hannover, Berlin, Weimar, Dresden: Richard Boorberg Verlag, 2009); [No author named], The Global Derivatives Market - An Introduction, White Paper (Deutsche Börse Group, Deutsche Börse AG / Eurex Frankfurt AG, 2008), p. 6; Ulrich Schüwer and Sascha Steffen, "§ 1 Funktionen und Einsatz von Energiederivaten [Chapter 1 Functions and Use of Energie Derivatives]": 33; in: Jean-Claude Zerey, ed., Außerbörsliche (OTC) Finanzderivate - Rechtshandbuch [Over the Counter Financial Derivatives - Legal Handbook], $1^{\text {st }}$ ed. (Baden-Baden: Nomos Verlagsgesellschaft, 2008).

96 Ibid.

97 Stefan Kirchner, supra note 95: 121; Ulrich Schüwer and Sascha Steffen, supra note 95 : 38 et seq.

98 Stefan Kirchner, supra note 95: 121.

99 Ibid.

100 Ibid.: 120.

101 Ibid.: 121

102 Ibid.
} 
between the product advertised and the product which is made available to the customer in the end. Religious concerns do not free regulators from this obligation. Rather, the advent of Islamic finance in non-Muslim countries provides another challenge to regulators. In this Islamic finance does not differ from other financial instruments. In either case investors must be protected against fraud. This is even more the case when investors' religious sentiments are at risk of being exploited by those who offer financial services. If done correctly, Islamic financial instruments can be valuable tools for faith-conscious Muslim investors, in particular immigrants. The current practice of Islamic finance, though, is often more oriented at the letter rather than the spirit of the law and the creation of ever new financial constructions throws doubts on the current practice in so far as in attempting to catch up with the modern world, Islamic finance to a large degree has lost touch with its roots. As a matter of fact, it has been noted that not speculation but rather "venture capital financing is the only truly Islamic way of financing and investing, because the banks become partners with their clients and share in the profits and [losses] of the businesses they finance." 103

In particular in the light of the recent experience of many small-scale investors with investment tools such as derivatives and the shadow banking industry at large during the ongoing financial crisis it appears necessary to regulate "Islamic" financial services like all other financial services in order to ensure that investors are not misled by religious labels which might include claims about financial products which investors are unable to verify.

\section{HUMAN RIGHTS ${ }^{104}$}

But do Western governments, in particular regulatory agencies, actually have to allow Islamic finance instruments in the first place? Or might they even be prevented from regulating such services due to the religious motivation for such investments?

Although some governments might want us to believe otherwise, ${ }^{105}$ freedom of religion is more than freedom of worship-it is the freedom to conduct one's entire life in accordance with one's faith.

\footnotetext{
103 Muhammed Saleem - Islamic Banking - A $\$ 300$ Billion Deception - Observations and Arguments on Riba (interest or usury), Islamic Banking Practices, Venture Capital and Enlightenment, $1^{\text {st }}$ ed., Xlibris, no location given (2005), p. 57.

104 This part of the article only deals with international human rights obligations stricto sensu and from a European perspective. For the legal status of Islam e.g. in Germany cf. Axel Freiherr von Campenhausen and Heinrich de Wall, Staatskirchenrecht [The Constitutional Law of Religious Communities], $4^{\text {th }}$ ed. (Munich: Verlag C. H. Beck, 2006), pp. 84 et seq.; Gerhard Czermak, Religions und Weltanschauungsrecht [The Law of Religions and World Views], $1^{\text {st }}$ ed. (Berlin/Heidelberg: Springer Verlag, 2008), pp. 115 et seq. For more detailed information about international human rights obligations of European countries concerning the freedom of religion cf. Malcom D. Evans, Religious Liberty and International Law in Europe (Cambridge: Cambridge University Press, 1997).
} 
To give an example which applies to all states which are members of the United Nations, Art. 18 of the Universal Declaration on Human Rights states that:

Everyone has the right to freedom of thought, conscience and religion; this right includes freedom to change his religion or belief, and freedom, either alone or in community with others and in public or private, to manifest his religion or belief in teaching, practice, worship and observance. ${ }^{106}$

The freedom of religion includes the right not only to worship but also the right to observance and the right to practice. It is less important for our purposes whether the prohibition of riba would fall into the category practice or observance, but the norm makes it relatively clear that at least the term "practice" can be understood in a way which goes beyond the mere freedom of worship.

Similarly, regional human rights guarantees allow for a wide understanding of the freedom of religion. From the perspective of immigrating Muslims, the European and American regional human rights systems are deserving of some attention.

Art. 12 of the American Convention on Human Rights reads as follows in paragraphs (1) and (3):

Everyone has the right to freedom of conscience and of religion. This right includes freedom to maintain or to change one's religion or beliefs, and freedom to profess or disseminate one's religion or beliefs, either individually or together with others, in public or in private. [...] Freedom to manifest one's religion and beliefs may be subject only to the limitations prescribed by law that are necessary to protect public safety, order, health, or morals, or the rights or freedoms of others. ${ }^{107}$

Art. 9 of the European Convention on Human Rights (ECHR) appears to be a bit more restrictive: ${ }^{108}$

105 James Heiser, "Obama Retreats From 'Religious Freedom' to 'Freedom of Worship'," The New American (July 19, 2010) // http://www.thenewamerican.com/index.php/usnews/constitution/4074obama-retreats-from-qreligious-freedomq-to-qfreedom-of-worshipq; Ashley Samelson, "Why 'Freedom of Worship' Is Not Enough," First Things (February 22, 2010) //

http://www.firstthings.com/onthesquare/2010/02/why-Idquofreedom-of-worshiprdquo-is-not-enough; Randy Sly, "Obama Moves away from 'Freedom of Religion' toward 'Freedom of Worship'?" Catholic Online (July 19, 2010) // http://www.catholic.org/national/national_story.php?id=37390; Sarah Eekhoff Zylstra, "'Freedom of Worship' Worries - New religious freedom rhetoric within the Obama administration draws concern," Christianity Today (June 22, 2010) //

http://www.christianitytoday.com/ct/2010/july/2.12.html; [No author named], "Obama und der Islam Verminderter Einsatz für die Religionsfreiheit?" (June 28, 2010) //

http://livenet.ch/neuigkeiten/international/166912-verminderter_einsatz_fuer_die_religionsfreiheit.html; Matthew Warner, "Obama Supports Your Freedom to 'Worship'?" National Catholic Register (July 5, 2010) // http://www.ncregister.com/blog/obama_supports_your_freedom_to_worship; Tony Beam, "Freedom of Religion Is More Than Freedom to Worship," The Christian Post (July 21, 2010) // http://www.christianpost.com/article/20100721/freedom-of-religion-is-more-than-freedom-to-worship; Tony Perkins, "My Take: President Obama's assault on Americans' first freedom," (August 16, 2010) // http://religion.blogs.cnn.com/2010/08/16/my-take-president-obamas-assault-on-americans-firstfreedom/?iref=obinsite.

106 Universal Declaration on Human Rights, G.A. res. 217A (III), U.N. Doc A/810.

107 American Convention on Human Rights, O.A.S.Treaty Series No. 36; 1144 U.N.T.S. 123.

108 On the freedom of religion under the ECHR cf. also Raymond Goy, "La Garantie Européenne de la Liberté de Religion," Revue du droit public 107 (1991). 
1. Everyone has the right to freedom of thought, conscience and religion; this right includes freedom to change his religion or belief and freedom, either alone or in community with others and in public or private, to manifest his religion or belief, in worship, teaching, practice and observance.

2. Freedom to manifest one's religion or beliefs shall be subject only to such limitations as are prescribed by law and are necessary in a democratic society in the interests of public safety, for the protection of public order, health or morals, or for the protection of the rights and freedoms of others. ${ }^{109}$

Although the wording of Art. 9 ECHR could suggest a more narrow interpretation, freedom of religion is by no means restricted to a mere freedom of worship. In order to be effective, freedom of religion has to include the right to live one's life in accordance with the rules and demands of one's religion. In order to square this real-life demand with the wording of Art. 9 ECHR, some authors, such as Anne Peters, claim that an action in order to be protected under Art. 9 ECHR needs to be in connection to the religion of the person who takes the action in question. ${ }^{110}$ Therefore the acting person needs to act not merely out of a personal conviction $^{111}$ or solely out of commercial interest ${ }^{112}$ but needs to be motivated by faith in order to claim rights in the context of the freedom of religion. We have to keep in mind the differentiation between the freedom of belief and the freedom to act based on a certain belief:

The scope of Art. 9 [of the European Convention on Human Rights], has generally been interpreted widely in terms of the nature of the belief (which includes non religious beliefs $[\ldots])$, but much more restrictively in relation to the manifestation or practices which are claimed to be motivated by one's religion or belief. The act in question must be 'intimately linked' to the religion or belief. Article 9 [of the European Convention on Human Rights] therefore does not protect every act which an individual considers to be required by their belief. ${ }^{[113] 114}$

But Art. 9 ECHR also protects the observance of religious customs, ${ }^{115}$ which include not only rituals but also everyday life. ${ }^{116}$ Customs can also include the prohibition of riba, although it seems more difficult to argue that the protection of

\footnotetext{
109 The current consolidated version of the Convention, up to date as of 1 June 2010, the date on which Protocol No. 14 entered into force, is available at: European Convention on Human Rights // http://conventions.coe.int/treaty/en/Treaties/Html/005.htm.

${ }_{110}$ Anne Peters, Einführung in die Europäische Menschenrechtskonvention [Introduction to the European Convention on Human Rights] (Munich: Verlag C. H. Beck, 2003), p. 181.

${ }^{111}$ Ibid., p. 182.

112 Ibid.

113 Cf. Arrowsmith v. United Kingdom, EComHR, Application No.7050/75, (1978) 19 DR 5; Haan and Chansh v. Bulgaria, ECtHR, Application No. 30985/96, 26 October 2000, (2002) 34 EHRR 55; Pichon and Sajous v. France, ECtHR, Application No. 49853/99, decision on admissibility of 2 October 2001.

${ }_{114}$ Philip Leach, Taking a Case to the European Court of Human Rights, $2^{\text {nd }}$ ed., Oxford University Press, Oxford (2005), p. 317; Malcom D. Evans, supra note 104, p. 305.

${ }_{115}$ Christoph Grabenwarter, Europäische Menschenrechtskonvention, $3^{\text {rd }}$ ed. (Munich: Verlag C. H. Beck, 2008), p. 243.

${ }^{116}$ Ibid., pp. 243 et seq.
} 
religious customs would also include access to one specific instrument of Islamic finance. The reason for this, though, is not so much the restrictiveness of international human rights law but the fact that many instruments of Islamic finance have been created so recently as to prevent them from having become customary by now. Even if they may have an old religious basis, these new and diverse financial instruments can hardly be argued to constitute a tradition. In fact, it could be argued, albeit in extremis, that even the prohibition of riba, that central element of Islamic finance, has failed to have become a true custom or tradition due to the fact that it is not fully clear what constitutes riba in the first place. This interpretation seems to be too far-reaching because there is, after all, a strong majority opinion on the interpretation of what constitutes riba. Also, custom does not require uniformity.

But even if one understands Islamic banking practices not to amount to a religious custom under Art. 9 ECHR, it can amount to a practice of one's faith in accordance with Art. 18 UDHR.

\section{REGULATORY CHALLENGES ${ }^{117}$}

\subsection{THE NEED FOR REGULATION}

Improved regulation not only could prevent a repeat of the large-scale fraud suffered by many investors in the 1990s (which recently entered into popular discourse thanks to Ben Verlong's movie Takiye: Allah'in Yolunda), it is also in the long-term interest of providers of Islamic financial services since it would not only improve the quality of the offered products but increased regulation would also make Islamic financial products more acceptable to a wider range of investors. That there is a general interest in ethically sound investments cannot be denied. Since the latest financial crisis there is a tangible unease with the stock market and certain financial products such as derivatives. Ethical financing practices can return the focus on the nexus between actual work and the profit derived from it. Here Islamic finance could play a role in the future - if it lives up to the ethical requirements enshrined in the sharia and the Quran. Muslim investors who take their faith seriously have to be given a chance to invest in a manner which is consistent with the teachings of the Quran. By fulfilling their tasks as regulators, national authorities can ensure that the active use of sharia-compliant finance instruments, which is one way in which to express one's religiosity, is also possible in states in which Muslims are only a minority. Yet, a meaningful role for Islamic

117 An overview over this issue, albeit limited to the situation in the United Kingdom and disregarding human rights issues, is provided by: Michael Ainley, Ali Mashayeki, Robert Hicks, Arshadur Rahman, and Ali Ravalia, supra note 11. 
finance requires that those who offer such financial instruments concern themselves not only with the form, the letter of the law, but also with the intention behind it, the ratio legis. As the sharia is a set of religious laws, we could only speculate as to the will of the divine lawmaker - but what all laws have in common is that the intent of the law is more important than its letter. That is not to say that we can violate the letter of the law as we see fit - on the contrary: as users of the law we are obliged (to the lawmaker as well as to all other users of the law) to try to understand the ratio legis.

In particular (but not only) when it comes to absolute truths embodied in religion, toleration also means allowing views with which one does not agree. ${ }^{118}$ But toleration has limits - which in this case are crossed when the religious faith as well as the good faith of an investor is abused for fraudulent purposes. The only licit way to allow for Islamic finance is to regulate it like any other financial service. In that way, the rules underlying Islamic finance would not be applied qua religion and the state would refrain from endorsing Islam, just like the state would not endorse Christianity when it allows ethical banking from a Christian perspective. Given that sharia law also contains rules which are incompatible with human rights, this appears to be the only realistic option if there is to be any place at all for Islamic banking in Western legal systems. Allowing for Islamic finance would thereby cease to be perceivable mainly as a tool for increased integration (although it would have this effect, to some degree); rather it would be merely an expression of the equal legal treatment afforded to religions in the pluralistic societies of Western Europe.

By allowing Muslim investors to use rules of Islamic Finance as long as they do not conflict fundamentally with the rules of the society at large (as would easily be the case if Western states were to allow sharia rules in criminal or family law ${ }^{119}$ as this would raise serious human rights issues and which is therefore not advocated here ${ }^{120}$ ), Western European States would indirectly give immigrants a reason to stay and, eventually, a sense of home. At the same time it would not deduct from our European identity since allowing the application of religious norms not qua religion but qua norm does not implicitly condone the religion in question;

${ }^{118}$ Cf. Beate Rossmanith, Tolerance in the field of bioethics from a Christian view, Licentiate Dissertation (Rome: Pontifical Athenaeum Regina Apostolorum, Faculty of Bioethics, 2010), p. 6. On the Christian view of other religions cf. Urszula Pękala, Eine Offenbarung - viele Religionen. Die Vielfalt der Religionen aus christlicher Perspektive auf der Grundlage des Offenbarungsbegriffs Wolfhart Pannenbergs [One Revelation - many religions. The multitude of religions from a Christian perspective on the basis of Wolfhart Pannenberg's understanding of the term revelation], $1^{\text {st }}$ ed. (Würzburg: Echter Verlag, 2010) [Bonner Dogmatische Studien Vol. 48], pp. 191 et seq.

${ }_{119}$ Against attempts to import sharia law in these fields Peter Unruh, Religionsverfassungsrecht, $1^{\text {st }}$ ed. (Baden-Baden: Nomos, 2009), p. 262.

${ }_{120}$ Cf. also Doriane Lambalet Coleman, "Individualizing Justice Through Multiculturalism: The Liberals' Dilemma," Columbia Law Review 96 (1996); Cathy Young, "Feminists' Multicultural Dilemma," Chicago Tribune (July 8, 1992): 15; Stanley Fish, "Religion and the Liberal State Once Again," The New York Times (November 1, 2010) // http://opinionator.blogs.nytimes.com/2010/11/01/religion-and-the-liberalstate-once-again. 
rather, it only means that we respect the faith of the other. It is possible to be more forthcoming to Muslim immigrants without surrendering Europe's Christian identity. Whether this will be done is a question of political will, but it is feasible to walk this thin line successfully. Facilitating the use of Islamic finance could be a step in this direction. As a matter of fact, the history of the mudéjares shows that there is a historic precedent for Muslims retaining their faith, language and judiciary while living under Christian rule. ${ }^{121}$ In the immediate aftermath of the reconquista the mudéjares suffered what would today be considered human rights violations, but if international human rights law is taken into account, a working solution based on respect for the faith of the other appears to be feasible in our day and age as well. If we remember the great contribution the mudéjares made during a time in which their rights were violated, how much more can they contribute to European societies today, when their human rights are respected?

\subsection{EQUAL REGULATION}

Because of the human rights of potential investors as well as of those working for Islam-oriented financial service providers, it has to be kept in mind that there is not only a negative, or defensive dimension to the human rights obligations included in human rights documents. Freedom of religion not only means that states may not limit religious activities, but it also has an active connotation: the positive obligation on the part of states to ensure that the freedom of religion can actually be exercised. This does not mean that the state has to construct churches, but it has to allow the construction of churches. In much the same way, the state does not have to offer Islamic finance services in state-owned banks, if there are any, but the state has to create the regulatory framework in which Islamic financial services may be offered. We can therefore conclude that it has to be permissible, in principle, under secular law to do business in accordance with one's faith, but that this does not mean that financial services which carry a religious label are exempt from regulation by national authorities. States are not required by human rights law to permit Islamic finance per se, that is, only because a faith-related label is used. Islamic financial services can be permitted qua financial service but there is no obligation on the part of the state to admit them merely qua religion. This is important for the discussion in those countries where politicians voice their opposition to any form of sharia law, not distinguishing between sharia rules which are incompatible with universal human rights standards on one hand and sharia

${ }^{121}$ Cf. Reinhard Wendt, Vom Kolonialismus zur Globalisierung - Europa und die Welt seit 1500 [From Colonialism to Globalisation - Europe and the World since 1500] (Paderborn, Munich, Vienna, Zürich: Verlag Ferdinand Schöningh, 2007), p. 25, there fn. 1. 
rules which are unproblematic in this regard on the other hand. If a financial product complies with the secular laws, it cannot be prohibited merely because it also happens to be sharia compliant at the same time as well.

One goal of the regulation of financial services is the protection of the customer, the investor who is seeking out specific financial services. Therefore it is necessary for regulators to familiarize themselves with Islamic finance. This is particularly so in countries in which Muslims are only a minority and where knowledge of Islam and the sharia is not yet as easily accessible as it is in predominantly Muslim countries or in predominantly Muslim countries with weak regulatory structures. Traditionally, three types of professionals are needed to set up new Islamic finance instruments: finance experts, sharia jurists and secular lawyers. In a legal system in which secular laws regulate financial services, it is the secular legislature which has to protect investors, thus increasing the importance of secular lawyers in the creation of Islamic financial products. At the same time, sharia jurists will have to ensure that new financial products are truly sharia compliant in order to reduce the risk of abuse of the label "Islamic" and fraud to the detriment of faithful Muslim investors. The investors' religious interests could be handled by sharia boards which are private institutions which work similarly to arbitral tribunals. They have no power to enforce their decisions but states may elect to recognize them, just as is done in cases of commercial arbitration. Some European legal cultures already allow arbitral awards to be enforced by state courts, provided basic requirements are met, such as respect for the ordre public and the basic rules of the legal order in question, including, of course, human rights and the consent of all parties to a dispute to be bound by the arbitral award. Such arbitral awards can be based on the sharia and in fact Britain already has a number of so-called Sharia Boards which decide issues of family law but also Islamic finance brought before them by Muslims on the basis of the sharia. ${ }^{122}$ Through allowing the establishment of private sharia boards the state would avoid having to rule on issues which are religious in nature while giving the faithful a chance for a forum where they can air their concerns. The state's regulatory work could then be limited to secular laws which do not differentiate on the basis of religion. Some countries have used similar methods for a long time in cases of family or inheritance law and given that family law can easily infringe human rights of those concerned, investment and banking issues appear to be far less sensitive. Islamic financial services can be regulated like any other service. As a consequence, they can be allowed under the same conditions. As we have seen before, human rights

122 On Sharia boards cf. Kent Rowey, Charles July, and Marc Fèvre, "Islamic finance: basic principles and structures - A focus on project finance," Freshfields Bruckhaus Deringer (London, 2006): 2 // http://www.freshfields.com/publications/pdfs/2006/13205.pdf. 
considerations do not require Islamic finance to be given a status apart from other financial services, but by effectively regulating them the state can help Muslims to enjoy their freedom of religion.

\subsection{RELIGION, TOLERANCE AND THE OBLIGATIONS OF THE STATE}

While the state would not decide whether a product is sharia compliant or not, taking religion out of the legal system is not a realistic option in Europe. Despite attempts by governments of many different persuasions, from the French Revolution to Bismarck's Kulturkampf, from the Third Reich to Communism, from the French secular state to the current culture of relativity which is reflected in law and politics, many have attempted to separate God and government. But the reality on the ground is different. People do believe, maybe not in the same relative numbers as in past centuries but faith is still relevant in European societies. As a matter of fact, after the miracle of European unity, if one looks at Europe as a whole, faith is more important now than it was at any time in the last hundred or so years, in particular in Eastern Europe. Any attempt to create laws which are disconnected from the Christian faith of the majority of Europeans is doomed to fail since it would not adequately reflect the society which every law has to serve. Law is at the service of society, including its weakest members, which sometimes have to be protected against the majority. In any case, law needs to be based on values. Law without values is mere technocracy and complete secularity is incompatible with the spiritual nature of Europe. Christian spirituality, although convinced of the truth of the message of Christ, includes respect for other faiths. The tolerance owed to other faith must not degrade into a relativism which no longer differentiates between right and wrong, but it must allow everybody to make a free choice in terms of religion. The fundament on which the legal culture of Europe is built can therefore be described as one of Christianity plus integrative tolerance up to the level of equal treatment for other religions.

\section{CONCLUSIONS}

There is no perfect neutrality of the state towards religions (except in states which suppress all forms of religion and favor atheism) and religiously motivated values continue to play a role in European legal systems, but de lege lata, states can only regulate Islamic finance qua finance but cannot make any executive pronouncements on the Islamic nature of any financial services offered. It is the compliance of service offers with secular, not with religious laws, which may be examined by the state. The approach suggested here is by no means directed 
against Islam. To the contrary, it is directed against all forms of relativism which denounce religion as such and which would allow atheism to become the de facto religion of the state and is intended to guarantee equal human rights for people of all faiths.

\section{BIBLIOGRAPHY}

1. Ainley, Michael, Ali Mashayeki, Robert Hicks, Arshadur Rahman, and Ali Ravalia. Islamic Finance in the UK: Regulation and Challenges. $1^{\text {st }}$ ed. London: Financial Services Authority, 2007.

2. Al-Rifal, Tariq, and Aamir Khan. "The Role of Venture Capital in Contemporary Islamic Finance." (2000) // http://www.kantakji.com/fiqh/Files/Finance/44437.pdf.

3. Beam, Tony. "Freedom of Religion Is More Than Freedom to Worship." The Christian Post (July 21, 2010) // http://www.christianpost.com/article/20100721/freedom-of-religion-is-morethan-freedom-to-worship.

4. Czermak, Gerhard. Religions und Weltanschauungsrecht [The Law of Religions and World Views]. $1^{\text {st }}$ ed. Berlin/Heidelberg: Springer Verlag, 2008.

5. Eekhoff Zylstra, Sarah. "'Freedom of Worship' Worries - New Religious Freedom Rhetoric within the Obama Administration Draws Concern." Christianity Today (June 22, 2010) // http://www.christianitytoday.com/ct/2010/july/2.12.html.

6. El-Gamal, Mahmoud Amin. "A Basic Guide to Contemporary Islamic Banking and Finance." (2000) // http://www.ruf.rice.edu/ elgamal/files.primer.pdf.

7. El-Gamal, Mahmoud Amin. Islamic Finance - Law, Economics and Practice. $1^{\text {st }}$ paperback edition, reprint. Cambridge, New York, Melbourne, Madrid, Cape Town, Singapore, Sâo Paulo, Delhi: Cambridge University Press, 2009.

8. El-Gamal, Mahmoud Amin. "Overview of Islamic Finance." Occasional Paper No. 4 (August 2006) ([United States] Department of the Treasury, Office of International Affairs) // http://www.ustreas.gov/offices/internationalaffairs/occasional-paper-series/08042006_OccasionalPaper4.pdf.

9. Evans, Malcom D. Religious Liberty and International Law in Europe. Cambridge: Cambridge University Press, 1997.

10. Fish, Stanley. "Religion and the Liberal State Once Again." The New York Times (November 1, 2010) // http://opinionator.blogs.nytimes.com/2010/11/01/religion-and-the-liberalstate-once-again. 
11. Fish, Stanley. "Serving Two Masters: Sharia Law and the Secular State." New York Times (October 25, 2010) //

http://opinionator.blogs.nytimes.com/2010/10/25/serving-two-mastersshariah-law-and-the-secular-state/.

12. Fröhlich, Anne-Sophie, and Claudia Stodte. "Islam von A bis Z [Islam from A to Z]." Der Spiegel Geschichte No. 5: Der Islam: 1400 Jahre Glaube, Krieg und Kultur [Islam: 1400 years faith, war and culture] (2010): 50 et seq.

13. Gassner, Michael. "How to Balance Form and Substance - The Role of Sharia Scholars." (August 11, 2008) // http://www.islamicfinance.de/?q=node/1461.

14. Goy, Raymond. "La Garantie Européenne de la Liberté de Religion." Revue du droit public 107 (1991): 5 et seq.

15. Grabenwarter, Christoph. Europäische Menschenrechtskonvention [European Convention on Human Rights]. $3^{\text {rd }}$ ed. Munich: Verlag C. H. Beck, 2008.

16. Greene, Richard Allen. "Mohammed tops list of English baby names." (October $29,2010) / /$

http://edition.cnn.com/2010/WORLD/europe/10/28/uk.mohammed/index.htm I?hpt=T2.

17. Habermas, Jürgen. "Leadership and Leitkultur." The New York Times (October $28,2010) / /$

http://www.nytimes.com/2010/10/29/opinion/29Habermas.html?pagewanted $=1 \& \_r=1 \&$ ref $=$ global-home.

18. Harvey, Leonard Patrick. Islamic Spain 1250 to 1500. Chicago: University of Chicago Press, 1990.

19. Heiser, James. "Obama Retreats from 'Religious Freedom' to 'Freedom of Worship'." The New American (July 19, 2010) //

http://www.thenewamerican.com/index.php/usnews/constitution/4074obama-retreats-from-qreligious-freedomq-to-qfreedom-of-worshipq.

20. Jobst, Andreas A. "Derivatives in Islamic Finance." (2007) // http://papers.ssrn.com/sol3/papers.cfm?abstract_id=1015615.pdf.

21. Jobst, Andreas A. "Risk Management of Islamic Finance Instruments." QFINANCE //

http://www.qfinance.com/contentFiles/QF01/94fqn4jz/10/0/riskmanagement-of-islamic-finance-instruments.pdf.

22. Jobst, Andreas A. "The Economics of Islamic Finance and Securitization." International Monetary Fund Working Paper WP/01/117 (2007) // http://www.imf.org/external/pubs/ft/wp/2007/wp07117.pdf.

23. Jomadar, Bushan K. "Islamic Finance and Securitization: Man-made Tale or Reality." Islamic Law and the Muslim World Paper No. 8-18 (2008) // 
http://ssrn.com/abstract=1093064.

24. Kirchner, Stefan. "Energiederivatehandel in Skandinavien - Voraussetzungen, Zugangsbedingungen und Entwicklungspotential [Energy Derivative Trading in Scandinavia - Requirements, Access Conditions and potential for Development]": 119 et seq. In: Nadine Ruppel, ed. Europäisches und Internationales Energiewirtschaftsrecht, Tagungsband des 9. Graduiertentreffens im Internationalen Wirtschaftsrecht in Gießen 2008 [European and international law of the energy business, Proceedings of the $9^{\text {th }}$ Postgraduate Meeting on International Economic Law in Gießen 2008]. $1^{\text {st }}$ ed. Stuttgart, München, Hannover, Berlin, Weimar, Dresden: Richard Boorberg Verlag, 2009.

25. Kirchner, Stefan. "Private Public Partnerships in Germany: Risk Allocation under the Concession Model." Legal Latitudes 1 (2007): 62 et seq.

Kirchner, Stefan. Public Private Partnerships: Das Konzessionsmodell beim Bau von Straßentunneln [Public Private Partnerships: the concession model in the construction of road tunnels]. $1^{\text {st }}$ ed. Munich: Grin Verlag für akademsiche Texte, 2007.

26. Lambalet Coleman, Doriane. "Individualizing Justice through Multiculturalism: The Liberals' Dilemma." Columbia Law Review 96 (1996): 1093 et seq.

27. Leach, Philip. Taking a Case to the European Court of Human Rights. $2^{\text {nd }}$ ed. Oxford: Oxford University Press, 2005.

28. Maalouf, Amin. Der Heilige Krieg der Barbaren - Die Kreuzzüge aus der Sicht der Araber [The Holy War of the Barbarians - The Crusades from the perspective of the Arabs]. $5^{\text {th }}$ ed. Munich: Deutscher Taschenbuch Verlag, 2008.

29. Mamat, Mohd Nor, Siti Fatahiyah Mahamood, Mohd Nazir Ahmad, Aliza Ismail, and Zam Hariro Jamaluddin. "E-Fatwa Information Management: Sustainance and Enhancement towards friendly and efficient online database." World Congress of Muslim Librarians and Information Scientists (November 25 - 27, 2008) //

http://ddms.usim.edu.my/bitstream/handle/123456789/1906/E-

Fatwa\%20Information\%20Management.pdf?sequence=1.

30. Netzer, Miriam Sophia. Riba in Islamic Jurisprudence - The Role of 'Interest', in Discourse on Law and State. $1^{\text {st }}$ ed. Medford: The Fletcher School, 2004.

31. [No author named]. "Al-Musharaka" // http://en.wikipedia.org/wiki/Al-Musharaka. 
32. [No author named]. "An Uncertain Road: Muslims and the Future of Europe Muslims and the Future of Europe." The Pew Forum on Religion and Public Life (October 19, 2005) // http://pewforum.org/Muslim/An-Uncertain-Road-Muslims-and-the-Future-ofEurope.aspx.

33. [No author named]. "Derivatives Dispute Divides Islamic Finance Market." Business Times (February 11, 2009) //

http://www.btimes.com.my/Current_News/BTIMES/articles/devisf/Article/prin t_html.

34. [No author named]. "Deutsche Bank Launches Shari`a Mutual Fund Capability - Initial Five Funds Unveiled in Dubai and Bahrain Today." Press Release (December 6, 2006) //

http://www.deutschebank.de/medien/en/content/press_releases_2006_3265.htm?dbiquery=null:is lamic\%20finance.

35. [No author named]. "Fundamentalisten sind überall [Fundamentalists are everywhere]": 24 et seq. In: Alain Gresh, Jean Radvanyi, Philippe Rekacewicz, Catherine Samary, and Dominique Vidal, eds. Atlas der Globalisierung [Atlas of Globalisation]. $2^{\text {nd }}$ ed. Paris: Le Monde diplomatique, 2010.

36. [No author named]. "Mehr Geld als Waren in der Welt [More money than goods in the world]": 66 et seq. In: Alain Gresh, Jean Radvanyi, Philippe Rekacewicz, Catherine Samary, and Dominique Vidal, eds. Atlas der Globalisierung [Atlas of Globalisation]. $2^{\text {nd }}$ ed. Paris: Le Monde diplomatique, 2010.

37. [No author named]. "Migration - viele Gründe, viele Grenzen [Migration many reasons, many borders]": 16 et seq. In: Alain Gresh, Jean Radvanyi, Philippe Rekacewicz, Catherine Samary, and Dominique Vidal, eds. Atlas der Globalisierung [Atlas of Globalisation]. $2^{\text {nd }}$ ed. Paris: Le Monde diplomatique, 2010.

38. [No author named]. "Mudarabah [Mudarabah]" // http://de.wikipedia.org/wiki/Mudarabah.

39. [No author named]. "Murabaha" // http://en.wikipedia.org/wiki/Murabaha.

40. [No author named]. "Obama und der Islam, Verminderter Einsatz für die Religionsfreiheit? [Obama and Islam, Reduced commitment to freedom of religion?]." (28 June 2010) // http://livenet.ch/neuigkeiten/international/166912verminderter_einsatz_fuer_die_religionsfreiheit.html.

41. [No author named]. "Riba" // http://en.wikipedia.org/wiki/Riba. 
42. [No author named]. The Global Derivatives Market - An Introduction, White Paper. Deutsche Börse Group, Deutsche Börse AG / Eurex Frankfurt AG, 2008.

43. [No author named]. "The Meaning of Islam" // http://www.wikiislam.net/wiki/The_Meaning_of_Islam.

44. Pękala, Urszula. Eine Offenbarung - viele Religionen. Die Vielfalt der Religionen aus christlicher Perspektive auf der Grundlage des Offenbarungsbegriffs Wolfhart Pannenbergs [One Revelation - many religions. The multitude of religions from a Christian perspective on the basis of Wolfhart Pannenberg's understanding of the term revelation]. $1^{\text {st }}$ ed. Würzburg: Echter Verlag, 2010 [Bonner Dogmatische Studien Vol. 48].

45. Perkins, Tony. "My Take: President Obama's assault on Americans' first freedom." (August 16, 2010) // http://religion.blogs.cnn.com/2010/08/16/my-take-president-obamasassault-on-americans-first-freedom/?iref=obinsite.

46. Peters, Anne. Einführung in die Europäische Menschenrechtskonvention [Introduction to the European Convention on Human Rights]. Munich: Verlag C. H. Beck, 2003.

47. Piotrowski, Dariusz. "Instrumenty pochodne na islamsim rynku finansowym Derivate Instruments on the Islamic Financial Market [Derivate Instruments on the Islamic Finance Market]." Bank i Kredyt (March, 2007): 40 et seq. // http://ssrn.com/abstract $=1007434$.

48. Reed, Clyde G., and Cliff T. Bekar. "Religious Prohibitions against Usury." (January 21, 1999) // http://www.appropriateeconomics.org/materials/Why\%20do\%20religions\%20prohibit\%20usury.htm.

49. Rosly, Saiful Azhar. "The role of the fatwa in Islamic finance." Investor Digest (January 16, 2003).

50. Rossmanith, Beate. Tolerance in the field of bioethics from a Christian view. Licentiate Dissertation. Rome: Pontifical Athenaeum Regina Apostolorum, Faculty of Bioethics, 2010.

51. Rowey, Kent, Charles July, and Marc Fèvre. "Islamic finance: basic principles and structures - A focus on project finance." Freshfields Bruckhaus Deringer (London, 2006) // http://www.freshfields.com/publications/pdfs/2006/13205.pdf.

52. Saleem, Muhammed. Islamic Banking - A $\$ 300$ Billion Deception Observations and Arguments on Riba (interest or usury), Islamic Banking Practices, Venture Capital and Enlightenment. $1^{\text {st }}$ ed. [No location given]: Xlibris, 2005. 
53. Samelson, Ashley. "Why 'Freedom of Worship' Is Not Enough." First Things (February 22, 2010) //

http://www.firstthings.com/onthesquare/2010/02/why-Idquofreedom-ofworshiprdquo-is-not-enough.

54. Schüwer, Ulrich, and Sasche Steffen. "§ 1 Funktionen und Einsatz von Energiederivaten [Chapter 1 Functions and Use of Energie Derivatives]": 33 et seq. In: Jean-Claude Zerey, ed. Außerbörsliche (OTC) Finanzderivate Rechtshandbuch [Over the Counter Financial Derivatives - Legal Handbook]. $1^{\text {st }}$ ed. Baden-Baden: Nomos Verlagsgesellschaft, 2008.

55. Shaukat, Mughees. General Perception of Fatwa and its Role in Islamic Finance. $1^{\text {st }}$ ed. Kuala Lumpur: INCEIF, 2009.

56. Sly, Randy. "Obama Moves away from 'Freedom of Religion' toward 'Freedom of Worship'?" Catholic Online (July 19, 2010) // http://www.catholic.org/national/national_story.php?id=37390.

57. Soumare, Cheikh A. The Principles of Islamic Banking [Thesis submitted to the International Institute of Islamic Banking and Economics, Girne, Turkey]. $1^{\text {st }}$ ed. [No location given]: Xlibris, 2008.

58. Stieber, Benno. "Allahs Banker [Allah's Banker]." enorm No. 4 (November 2010 - February 2011): 112 et seq.

59. Stüssi, Marcel. "Banning of Minarets: Addressing the Validity of a Controversial Swiss Popular Initiative." Religion and Human Rights 3 (2008): 135 et seq.

60. Sundararajan, V., and Luca Errico. "Islamic Financial Institutions and Products in the Global Financial System: Key Issues in Risk Management and Challenges Ahead." International Monetary Fund Working Paper WP/02/192 (2002) //

http://papers.ssrn.com/sol3/papers.cfm?abstract_id=880303.

61. Terwitte, Paulus. Das Leben findet heute statt! Ein Anschlag auf die Vertröstungsgesellschaft [Life happens today - An attack against the society of promises for the future]. $1^{\text {st }}$ ed. Reinbek bei Hamburg: Rowohlt, 2009.

62. Unruh, Peter. Religionsverfassungsrecht. $1^{\text {st }}$ ed. Baden-Baden: Nomos, 2009.

63. Von Campenhausen, Axel Freiherr, and Heinrich de Wall. Staatskirchenrecht [The Constitutional Law of Religions Communities]. $4^{\text {th }}$ ed. Munich: Verlag C. H. Beck, 2006.

64. Warner, Matthew. "Obama Supports Your Freedom to 'Worship'?" National Catholic Register (July 5, 2010) // http://www.ncregister.com/blog/obama_supports_your_freedom_to_worship. 
65. Wendt, Reinhard. Vom Kolonialismus zur Globalisierung - Europa und die Welt seit 1500 [From Colonialism to Globalisation - Europe and the World since 1500]. Paderborn, Munich, Vienna, Zürich: Verlag Ferdinand Schöningh, 2007.

66. Young, Cathy. "Feminists' Multicultural Dilemma." Chicago Tribune (July 8, 1992).

\section{LEGAL REFERENCES}

1. American Convention on Human Rights. O. A. S. Treaty Series No. 36; 1144 U.N.T.S. 123.

2. Arrowsmith v. United Kingdom. EComHR. Application No.7050/75, (1978) 19 DR 5.

3. European Convention on Human Rights (Convention for the Protection of Human Rights and Fundamental Freedoms) // http://conventions.coe.int/treaty/en/Treaties/Html/005.htm.

4. French Law No. 524 of July 13, 2010 [prohibiting the covering of one's face in public] // http://www.assemblee-nationale.fr/13/ta/ta0524.asp.

5. Haan and Chansh v. Bulgaria. ECtHR. Application No. 30985/96, 26 October 2000, (2002) 34 EHRR 55.

6. Pichon and Sajous v. France. ECtHR. Application No. 49853/99, decision on admissibility of 2 October 2001.

7. Universal Declaration of Human Rights. G.A. res. 217A (III), U.N. Doc A/810. 